Vol. 01, No. 2, July 2017, 121-140

Avalaible at: https://ojs.unud.ac.id/index.php/UJLC

E-ISSN 2549-0680

\title{
Regulating Indigenous Culture as a Tourism Economic Resource
}

\section{Made Suksma Prijandhini Devi Salain*}

Faculty of Law Udayana University, Bali, Indonesia

\author{
David Isles $^{* *}$
}

Charles Darwin University School of Law, Darwin, Australia

\section{Gusti Ngurah Wairocana ${ }^{* * *}$}

Faculty of Law Udayana University, Bali, Indonesia

\begin{abstract}
There have been some cases indicating the dissatisfaction of traditional communities with regards to tourism that does not economically contribute to their cultural activities. The legal issue raised in this writing the lack of, or maybe the abstention of, a regulation that specifically regulates indigenous culture as a tourism economic resource. This article is aimed at describing and analyzing relevant international and national instruments that regulate the issues of indigenous culture and economic activities of tourism. The cases of Indonesia, especially Bali, compared with Australia are the focus of this article. It has been found that Indonesian laws and regulations are insufficient to protect culture as a tourism economic resource. In contrast, Australia has adopted a trichotomous approach wherein economic, social and cultural factors are separate and can be managed separately, an approach that has had mixed results.
\end{abstract}

Keywords: Indigenous People, Culture, Economic Resource, Tourism, Law.

How to Cite: Devi Salain, Made Suksma Prijandhini, David Isles, and I Gusti Ngurah Wairocana. 2017. "Regulating Indigenous Culture As A Tourism Economic Resource". Udayana Journal Of Law And Culture 1 (2): 121-140. doi:10.24843/UJLC.2017.v01.i02.p03.

DOI: https://doi.org/10.24843/UJLC.2017.v01.i02.p03

Copyright (C) 2017 UJLC. All right reserved

\section{Introduction}

\subsection{Background}

The actual case occurring in the Ulun Danu Beratan ${ }^{1}$ tourist destination area, Tabanan, Bali-Indonesia, is shocking to the tourism actors. It was in July 2017 when tens of people wearing traditional customs suddenly put up banners containing statements regarding the temporary closure of Ulun Danu Beratan temple. For years,

* Correspondence: suksmadevi@gmail.com.

** Correspondence: zzdisles@netscape.net.

*** Correspondence: wairocanangurah@yahoo.co.id.

${ }^{1}$ Ulun Danu Beratan is one of the famous temples which is located in Bedugul-Bali. It is an example of a place for praying that is also cultural tourism destination. The way of indigenous people praying in the Temple is a part of the local culture while also being a tourism attraction. The Indigenous people around the Ulun Danu Beratan Temple, as the owners of the temple and traditions practiced there, were seen to not be getting an appropriate benefit from tourist activities. 
the temple and its surrounding area had been designated as a tourist destination. Some people believe that this problem arose because of the unclear profit-sharing in the internal management of the temple. ${ }^{2}$ A mediation process was carried out in the office of the tourism destination before officers of the Civil Service Police Unit, accompanied by local police personnel, then withdrew the banners. ${ }^{3}$

The abovementioned case is one example of the other problems arisen related to the impact of tourism on host communities in Bali. Research also discovered unpleasant relations that have occurred with regards to profit sharing in some temples in Bali where the locations are integrated with tourism destinations. ${ }^{4}$ The finding shows that the policy-making process and inequity of roles and profit distributions between the stakeholders have initiated the long-lasting conflict. ${ }^{5}$

It should be acknowledged that there is a cost to maintain cultural life in Bali. It has been estimated that Hindu peoples in Bali spend about IDR. 600.000.000.000 per month just for the daily ceremonial activities required to maintain their cultural life. ${ }^{6}$ The traditional community, as the owner of the culture, does not seem to get benefits from the use of the culture as they flow only to the Government and the private sector. ${ }^{7}$ Those conditions are caused by the lack of an economic relationship between the traditional community, the Government, and the private sector. ${ }^{8}$

The traditional community has, for centuries, organized in a Desa Pakraman as a unit of the traditional community which follows Hindu traditions, and has a social structure through the Kahyangan Tiga bond, its own territory, and properties. This Desa Pakraman also has the right to self-regulation as long as any regulations are not contrary to the Indonesian Constitution. ${ }^{9}$ The term desa in Bahasa Indonesia can be translated into the village. For Balinese peoples, this term can be associated with two meanings. First, Desa Dinas, a village that has unity of Government administration

2 http://bali.tribunnews.com/2017/07/26/ini-alasan-pura-ulun-danu-beratan-ditutup-puluhan-orang-berpakaian-adat.

3 http://www.jawapos.com/radarbali/read/2017/07/26/3807/gawat-objek-wisata-danau-beratandisegel-warga.

4 I Nengah Subadra, I Wayan Arta Artana, I Made Bayu Wisnawa, "Pura di Tanah Lot: Konflik di Obyek dan Daya Tarik Wisata Global," Jurnal Perhotelan dan Pariwisata 6, No. 1 (2016): 60-61. doi: https://subadra.files.wordpress.com/2016/10/i-nengah-subadra-jurnal-2016-pura-tanah-lot-konflik-diobyek-dan-daya-tarik-wisata-global.pdf.

5 Ibid., 1.

6 See I.B. Wyasa Putra, "A Contra-productive Impact of Indonesian New Legislation on Administrative Village against Indonesian Indigenous Culture as an Economic Resources," International Conference on Access to Justice for Indigenous Peoples, Malaya: Faculty of Law University of Malaya, 2015. 2-3 and Made Suksma Prijandhini Devi Salain, Perlindungan Hukum terhadap Bali sebagai Sumber Daya Ekonomi Pariwisata, Kertha Patrika 39, No. 1 (2017): 1-15 https://ojs.unud.ac.id/index.php/kerthapatrika/article/ view/32705

7 Ibid.

8 Ibid.

9 I Nyoman Sirtha, Aspek Hukum Dalam Konflik Adat Bali (Denpasar: Udayana University Press, 2008), 1 and See Indonesian Village Act No. 6 Year 2014 and Indonesian Local Government Act No. 23 Year 2014. 
territory. Secondly, Desa Adat or Desa Pakraman, a unity territory of the indigenous people (Balinese society). ${ }^{10}$

Due to relatively autonomous governance and strong community identification, some Desa Pakraman, for example, Penglipuran village ${ }^{11}$ are able to organize their cultural activities as a tourist attraction and as a result, return a benefit to the village itself. Vice Chairman of the Regional House of Representatives of the BangliRegency assessed that the management of existing tourist destinations in Bangli regency, including Penglipuran village, has not been maximized. He emphasized that customary villages must be granted an involved role by the local government. ${ }^{12}$

The above example cannot be broadly generalized as it has not happened in all Desa Pakraman in Bali. In Kuta, for example, ${ }^{13}$ only a few tourists like to watch the Balinese traditional dance performances as it seems tourists in that area prefer to enjoy the night entertainment. There are also some other villages that have been changing from the cultural tourism destinations into more mainstreamed global tourism. That change maybe assumed to decrease the source of income for the traditional community, because there is less economic benefit derived from Balinese culture.

The situation in Bali-Indonesia may be compared to its neighbouring country, Australia, a continent where indigenous people called Aborigines, or Indigenous Australians, are living. In Australia, Aboriginal cultural products are broadly spread across numerous facilities and activities, such as cultural tours with guides, art centers, art performances, art galleries, monuments, sites of heritage and also the opportunity to come to see the real life of Aborigines. The content of Aboriginal culture is related to their beliefs (totemism), relationships between them, the way of life (how to get and prepare food), trading systems, ceremonial activities (art, dance, and music) and their herbal medicines. ${ }^{14}$

Contrasted with the Balinese, whom are the majority population in Bali, Aborigines are now a small proportion of the Australian population. The Balinese daily life is part of the culture and is also utilized as the core of tourism in Bali, which has made Bali

10 See I Ketut Sudantra, 2007, Pelaksanaan Fungsi Hakim Perdamaian Desa dalam Kondisi Dualisme Pemerintahan Desa di Bali, Thesis, S2 Ilmu Hukum Program Pasca Sarjana Universitas Udayana, 43-52; See also Article 6 (1) of Act No. 6 Year 201 concerning Village: "Village comprises Desa/Desa Dinas and Desa Adat".

11 Penglipuran Village is a traditional village which is located in Bangli. The term of "Penglipuran" is originated from "Pengeling Pura" that means always remember to the temple, the God and the ancestor. The infrastructure of the Penglipuran is far away from modernization. All of the houses in the Penglipuran have a same architecture and room layout. They have a unique tradition, such as they are sleeping in the kitchen. As we know, kitchen is a place to cook some food. They are maintaining those conditions in order to keep their traditions and still being the tourism attraction at one.

12 http://www.balipost.com/news/2017/04/30/7149/Wajib-Libatkan-Desa-Adat-Dalam.html.

13 Kuta is a famous place that located in Badung Regency. A lot of tourists especially the youth tourist love to stay and enjoy the entertainment at Kuta.

14 Kirstie Lowe and Stephen Ollerenshaw, "Cultural Tourism Development Program An Introduction to the Tourism Industry and Business Development," http://www.environment.nsw.gov.au/resources/ parksecopass/CTDProgram.pdf, 9-15. 
as a worldwide cultural tourism destination. As far as it is concerned, the Aboriginal culture has not yet been progressively developed as a core element of Australian tourism. Based on data from New South Wales Destination by year-end in December 2016, only $9.5 \%$ of foreign tourists visited Aboriginal sites or communities, and just $8.5 \%$ attended Aboriginal cultural performances. ${ }^{15} \mathrm{~A}$ lot of tourists come to Australia to visit the more remote natural environments and provide an explanation of the places including the wildlife, such as Great Barrier Reef, Uluru/Ayers Rock, Kakadu National Park, the Whitsunday Islands, the Blue Mountains National Park, or the Purnululu National Park. Thus, Australia is known as an ecotourism destination. ${ }^{16}$

\subsection{Legal Issues and Purpose of Writing}

Economics and Tourism studies seem to believe that tourism is an effective tool to stimulate the economy of a country or region. Further, tourism may also affect tourism poverty in direct, indirect, or dynamic pathways. ${ }^{17}$ The concept of indigenous culture that is discussed in this article is Hadjionnou's much looked at description that defines it as the core body of beliefs, knowledge, traditions and way of life that is passed on from generation to generation in indigenous communities that forms an integral part of the lives of indigenous peoples and are manifested in the form of ancestor worship, religious or spiritual ceremonies, oral traditions and rituals which have been passed down through the generations. ${ }^{18}$

The fundamental legal issue in this article is the lack of, or maybe abstention of, laws and regulations that specifically regulate indigenous culture as a tourism economic resource. It will primarily look at the example of Indonesia, especially Bali, and at Australia's concern in protecting their indigenous culture. Thus, this article is aimed to describe and analyze instruments that regulate the issue of indigenous culture and economic activities of tourism. These include relevant international instruments, Indonesian law and regulations (including local regulation of Bali Province), and some Australian laws as a comparison.

15 New South Wales Destination, "Cultural and Heritage Tourism to NSW Year Ended December 2016," https://www.destinationnsw.com.au/wp-content/uploads/2013/05/Cultural-and-Heritage-Tourismto-NSW-Snapshot-YE-Dec-2016.pdf

16 Top 10 Tourist Attractions in Australia, www.touropia.com/tourist-attractions-in-australia/ The ecotourism has some elements i.e.: offer a direct experience; sighting to the natural places, educate the tourists about the places including how to protect; conserve in order to diminish the negative impact to the environment and the ecotourism itself should give the benefits to the local economy.

17 Caroline Ashley, Peter de Drine, Amy Lehr, and Hannah Wilde, "The Role of the Tourism Sector in Expanding Economic Opportunity," Corporate Social Responsibility Initative Report, No. 23, Cambridge, MA: Kennedy School of Government, Harvard University, (2007): 8-9. https://pdfs.semanticscholar.org/c9 bf/52b9103069edcf80a8d669dde0d5c28b1853.pdf.

18 Amanda Barratt and Ashimizo Afadameh-Adeyemi, "Indigenous peoples and the right to culture: The potential significance for African indigenous communities of the Committee on Economic, Social and Cultural Rights' General Comment 21," African Human Rights Law Journal 11, No. 2 (2011): 565. See also the meaning of 'culture' that is used in the specific context of (Aboriginal) traditional Indigenous cultures and their persistence within a 'mainstream' culture in Simon Colquhoun and Alfred Michael Dockery, "The link between Indigenous culture and wellbeing: Qualitative evidence for Australian Aboriginal peoples", CLMR Discussion Paper Series 01, (2012):3. http://ceebi.curtin.edu.au/local/ docs/2012.01_LSIC_qualitative_CLMR1.pdf. 


\subsection{Research Methodology and Article Outline}

This article is a normative research paper that analyses and interprets the relevant rules, explains the areas that should be reformed and predicts the possibility to create future laws. ${ }^{19}$ The analysis is focused on primary sources of law contained in international instruments and statutes (Acts and Local Regulations), as well as secondary sources (the concept of laws that provided in journals, books, and the internet). ${ }^{20}$ Perspectives in this writing are enriched by statute, comparative, and fact-based approaches. It should be acknowledged that this article further develops joint research ${ }^{21}$ and previous publication, ${ }^{22}$ that has been rewritten. This version adds some relevant facts and analysis of relevant international instruments.

The outline of this article is construed as follows. First, the introduction section will describe the reason why the indigenous culture international instruments and relevant Indonesian and Australian laws and regulations. Afterward, it is continued to interpret and elaborate on those international instruments and domestic regulations in order to check the sufficiency of the recognition and protection of the indigenous culture as a tourism economic resource. Subsequently, this section will provide the appropriate approach to make a new policy in Indonesia to maintain the sustainability of indigenous cultures. Finally, the article will make conclusions and recommendations based on the aforementioned analysis.

\section{Result and Discussion}

\subsection{International Instruments that Recognizes the Rights of Indigenous Peoples}

There are several international instruments that relate to the indigenous people and their culture. For example, both Indonesia and Australia derive some of their domestic laws pertaining to indigenous peoples from international instruments. Both countries have also ratified the International Covenant on Economic, Social and Cultural Rights 1966 (ICESCR ${ }^{23}$ and endorsed the United Nations Declaration on the Rights of Indigenous Peoples 2007 (UNDRIP). ${ }^{24}$ The State parties of the ICESCR shall guarantee that the rights (economic, social, cultural) under the covenant will be

19 Soerjono Soekanto and Sri Mamudji, Penelitian Hukum Normatif: Suatu Tinjauan Singkat (Jakarta: Raja Grafindo Persada, 2001), 2-6 in Depri Liber Sonata, "Metode Penelitian Hukum Normatif dan Empiris: Karakteristik Khas dari Metode Meneliti Hukum”, Fiat Justisia Jurnal Ilmu Hukum 8, No.1 (2014): 25 https://doi.org/ 10.25041/fiatjustisia.v8no1.283 and See Terry Hutchinson, Researching and Writing in Law, (Sydney: Lawbook Co., 2002), 9.

20 Laire De Marco, "Legal Research Strategy," http://guides.library.harvard.edu/law/researchstrategy/primarysources and I Made Pasek Diantha, Metodologi Penelitian Hukum Normatif dalam Justifikasi Teori Hukum, (Jakarta: Prenada Media Group, 2016), 149-151.

21 Previous research carried out by First and Second authors, supervised by Ida Bagus Wyasa Putra, December 2015.

22 Salain, loc.cit.

23 Indonesia ratified the ICESCR on 23 February 2006

24 Australia endorsed the declaration in 2009. 
enjoyed by their citizens under the-discrimination principle. ${ }^{25}$ Especially for cultural rights, it should be recognized that everyone has the right to participate in cultural life and get the benefits from it. ${ }^{26}$ The terminology of 'everyone' means that every individual, including indigenous peoples. Thus, the international community recognizes the existence of the indigenous people and the indigenous people themselves as the owner of the indigenous culture and have the right to participate in cultural sustainability and enjoy the benefits. Cultural sustainability and cultural benefits are interrelated. From the benefits, the indigenous people can maintain the cultural sustainability and if the culture is constantly sustainable, it will give benefits.

The UNDRIP is not a binding instrument but it shows the commitment of the United Nations members to recognize and protect the rights of the indigenous people all over the world. Same as the Universal Declaration of Human Rights (UDHR) 1948, in the beginning, it is a declaration but eventually will become a basic norm for all human rights instruments (internationally and nationally). Referring to Article 3 of the UNDRIP, "The indigenous people have the right to self-determination." Article 3 means they are free to determine their cultural development. This includes the right to practice, revitalize, maintain, protect and develop the past, present and future variety of their cultural traditions and customs. ${ }^{27}$ It should be noted that the participation of different Indigenous peoples in the United Nations Open-Ended Working Group during the creation of UNDRIP is one example of utilizing the Indigenous peoples's approach. As analyzed by Brenda L. Gunn, such active participation in the drafting and negotiation process enabled various Indigenous peoples to articulate their rights in a way that is meaningful to them. ${ }^{28}$

In addition to the ICESCR and UNDRIP, the International Labour Organisation (ILO) Convention on Indigenous and Tribal Populations 1957 (No. 107) ${ }^{29}$ and the ILO Convention on Indigenous and Tribal Peoples 1989 (No. 169), although not ratified, indicate how the international community views the economic, social, cultural rights and status of indigenous peoples. It is often the principles espoused in these instruments that have been implemented in domestic laws.

With regards to the concern that culture is one of the tourism elements, both The Global Code of Ethics for Tourism (GCET) and General Agreement on Trade in Services (GATS) are international instruments that should be read. GCET is used as a frame to minimize the negative effect on tourism development and maximize

25 ICESCR, Article 2 paragraf 2.

26 Ibid., Article 15 paragraf 1.

27 UNDRIP, Article 11.

28 Brenda L. Gunn, "Protecting Indigenous Peoples' Lands: Making Room for the Application of Indigenous Peoples' Laws Within the Canadian Legal System," Indigenous Law Journal 6, Issue 1, (2007): 59-60, http:/ /ilj.law.utoronto.ca/sites/ilj.law.utoronto.ca/files/media/ilj-6.1-gunn.pdf.

29 This conventions was a first attempt to codify international obligations of States in respect indigenous and tribal populations. 
the benefits from it to reduce poverty. This code contains nine (9) principles of tourism sustainable development which are already implemented by seventy percent (70\%) of the United Nations members into their national laws. ${ }^{30}$ Based on Article 4 of the GCET, tourism has two roles - as a user of the culture and as a contributor to its development. Tourism activities should give benefits to the host countries and communities (including the indigenous people) as the owners of the culture. ${ }^{31}$ This shows that tourism has a relationship with culture.

Another international instrument that is simultaneously related to tourism and culture is GATS that was enacted by the World Trade Organization (WTO) to arrange international services trading. GATS has a different concept to the GCET. On one hand, GCET upholds the sustainable development concept for tourism while on the other hand GATS uses the trading concept in managing tourism. When tourism is considered as a part of services trading systems, there are economic resources to support the implementation of the tourism itself. Economic resources are factors which could be used to produce goods and services in order to gain a benefit. There are also human resources (the ability of entrepreneurial, management, labor) and non-human resources as economic resources (capital in goods and financial, land, technology). ${ }^{32}$ In relation to tourism as a part of services trading systems, the indigenous Balinese culture is a human economic resource (as the owner of the indigenous Balinese culture) and non-human economic resource (the traditions; the ceremonies). The economic resource is the fundamental elements of the tourism because without it the tourism will collapse. It is fact that every WTO member has different economic resources for their tourism. Thus, the recognition and protection of the economic resources into an appropriate regulation are definitely needed.

\subsection{Indonesia Regulations $\mathbf{s}^{33}$}

In Indonesia, culture is an economic resource for tourism, but unfortunately, there is no specific regulation that covers the issue.As far as it is concerned, some substantial and partial rules contained in regulations related to the indigenous peoples and their culture. The most significant law is the 1945 Constitution of the Republic of Indonesia that recognizes and respects the customary law of traditional

30 General Assembly of the United Nations, A/65/275, Sixty-Fifth Session, Item 20 of the provisional Agenda, "Sustainable Development, Implementation of the Global Code of Ethics for Tourism", 10 August 2010, http://cf.cdn.unwto.org/sites/all/files/pdf/item_7a.pdf.

31 GCET, Article 5.

32 This conventions was a first attempt to codify international obligations of States in respect indigenous and tribal populations.

33 See also some analysis in this part in Putri Triari Dwijayanthi, Kali Watson, Ni Gusti Ayu Dyah Satyawati, "Indigenous People, Economic Development and Sustainable Tourism: A Comparative Analysis between Bali, Indonesia and Australia," Udayana Journal of Law and Culture [S.1.] 1, No. 1 (2017): 1920, https://doi.org/10.24843/UJLC.2017.v01.i01.p02 and Made Suksma Prijandhini Devi Salain, op. cit, $5-8$. 
communities and their traditional rights. ${ }^{34}$ The indigenous people also have civil, political, economic, social, and cultural rights as stipulated in Article $28 \mathrm{C}(1)^{35}$, Article 28 I (3) ${ }^{36}$ and Article 32 of the Indonesian Constitution. ${ }^{37}$ These protections mean that all indigenous peoples in Indonesia could maintain, develop and enjoy the benefits of their culture. Case law proved that the indigenous people in Indonesia have legal standing before the court. For example, the Constitutional Court of Indonesia issued judgments regarding the forest right of the indigenous people (Kenegerian Kuntu) in Kampar Region-Riau Province and the indigenous people (Kasepuhan Cisitu) in Lebak Region-Banten Province. ${ }^{38}$

The second instrument is the Indonesian Human Rights Act No. 39 Year 1999. Article 6 of this Act stipulate as follows:

(1) "In the interests of upholding human rights, the differences and needs of indigenous peoples must be taken into consideration and protected by the law, the public and the Government;

(2) The cultural identity of indigenous peoples, including indigenous land rights, must be upheld, in accordance with the development of the times."

The Act gives protection to the differences and needs of indigenous peoples including the cultural identity and indigenous land rights on the basis of human rights. If an individual, group of peoples or stakeholders do not respect and protect the existence of the indigenous peoples then they could breach these human rights.

The third piece of legislation is the Indonesian Village Act No. 6 Year 2014. In Article 103 (3) (c) it holds that "The authority of Desa Adat based on origin rights are.....preservation of the social culture values.....". As further regulated, the authority at least consists of: the organizational system of the indigenous people, community

34 It reflected in Article 18 B (2) : "The state shall recognize and respect customary law (hukum adat) community units along with their traditional rights insofar as they are still in existence and are in conformity with the development of society and the principle of the Unitary State of the Republic of Indonesia, as regulated by law".

35 Every person shall have the right to develop him/herself through the fulfillment of their basic needs, shall have the right to obtain education and to enjoy the benefits of science and technology, arts and culture, for the enhancement of the quality of their life and for the welfare of the humankind.

36 The cultural identity and the rights of traditional communities shall be respected in conformity with the development of time and civilization

37 The state shall advance the national culture of Indonesia amidst world civilization by guaranteeing freedom to the society in preserving and developing its cultural values.

38 See Indonesia Constitutional Court Decision No. 35/PUU-X/2012.. In this case, the Aliansi Masyarakat Adat Nusantara (AMAN), the indigenous people of Kenegerian Kuntu and Kasepuhan Cisitu act as the Complainant. They brought the case before the Constitutional Court in accordance to examine the substance of the Forestry Act No. 41 Year 1999 against the Indonesian Constitution. This case begins when the Government used the Forest Act to confiscate the right of the indigenous people of the indigenous forest territorial as the State Forest. The Government gave license to the investor in exploring; exploiting the natural resources of the forest without respecting the indigenous people local wisdoms. Those situations induced conflict between the indigenous people and the investors. See also Article 51 (1) of the Constitutional Court Act No. 24 Year 2003 juncto Article 3 of the Constitutional Court Regulations No. 06/PMK/2005 concerning the Guideline of the Judicial Review Procedures: "The Complainant are: (a) Individual (Indonesia Nationality); (b) The Indigenous people; (c) Corporation (public and private); (c) State organs". 
institutional development, institution and Adat law development, management of the land owned by the village and development of the indigenous people's role. ${ }^{39}$ Referring to those articles, Desa Adat has the right to preserve their culture through their institution which involves the indigenous people as the owner of the indigenous culture.

The Indonesian Tourism Act No. 10 Year 2009 empasizes that culture is one of the tourism development pillars, but it does not recognize and protect culture as a tourism economic resource. ${ }^{40}$ According to Article 1 (5) of the Indonesia Tourism Act juncto Article 1 paragraph 8 of the Government Regulation No. 50 Year 2011 concerning Master Plan of National Tourism Development Year 2010 - 2025: "Tourism attraction power is all matters having uniqueness, beauty, and value in the form of various natural wealth, culture, and the man-made product as the target or objective of the tourists visit." The culture one of the drivers of tourist attraction to Indonesia. As a driver of tourist attraction, the indigenous peoples could take apart maintaining and developing their culture. ${ }^{41}$ The development of culture is based on Indonesian Tourism principles with due observance of the diversity, uniqueness and typical culture and nature, and the human needs for tourism. ${ }^{42}$ In contrast, the Indonesian Culture Heritage Act No. 11 Year 2010 treats culture as a sign of human civilization.

At the provincial level, Regulation of Bali Province No. 3 Year 2001 concerning Desa Pakraman should be considered. The consideration part of this regulation makes clear that Desa Pakraman, as the unity of the indigenous people which is imbued with Hinduism and Balinese cultural values, plays a big role in religion and social culture. Thus, Desa Pakraman needs to be protected, preserved and empowered. The existence of Desa Pakraman is recognized and protected by the Government and also given autonomic right to conduct and manage their existence because they have an important role in the development of their economy, society, and culture. ${ }^{43}$ In addition to autonomy rights, Desa Pakraman also has the following obligations under Article 5 of this provinvial regulation:"(a) make a law (awig-awig); (b) regulate its citizen (krama desa); (c) manage the wealth of Desa Pakraman; (d) together with the Government to conduct the development in all area especially in religion, culture and society; (e) develop the Balinese culture values in order to enrich, conserve, maintain the national and region culture which is based on deliberation-consensus (paras-paros; sagilik-saguluk; salunglung-sabayantaka); (f) protect its citizen."

The Regulation of Bali Province No. 2 Year 2012 explicitly governs Cultural Tourism of Bali. The objectives of Balinese Cultural Tourism are to conserve Balinese culture, which is imbued by Hindu values, to increase economic growth, to increase

39 Government Regulation No. 47 Year 2015 concerning the Amendment of the Government Regulation No. 43 Year 2014 on the Implementing Regulation of the Village Act No. 6 Year 2014, Article 34 (1).

40 Indonesian Tourism Act, Articles 1 (5) and (6).

41 Ibid., Article 5 (e).

42 Ibid., Article 6.

43 Regulation of Bali Province concerning Desa Pakraman, Consideration paragraph (b). 
social welfare, to create employment, to conserve nature, the environment, and resources. ${ }^{44}$ From these objectives, the primary basis of the Culture of Bali Tourism is culture itself. If the Balinese culture is well maintained it would increase social welfare and create employment, which means culture has commercial and economic value. In fact, the cost of daily ceremonies that is spent by the Balinese indigenous peoples to preserve the culture is not giving a direct economic benefit to them as the benefits mainly flow to the Government and the private sector. It can be regarded that such an unjust situation is caused by the lack of regulation that determines culture as a tourism economic resource.

\subsection{The Case of Australia}

The issue of the involvement of Aborigines as Australian indigenous peoples in tourism acts as a comparison to the Balinese case. A long-time structural disadvantage experienced by Aborigines led to a discussion on the value of preserving the Aboriginal culture and protecting their indigenous rights. ${ }^{45}$

Altman and Finlayson studied how some factors may become important pre-requisites for successful and sustainable Aboriginal participation in tourism, namely: Aboriginal control, market realism for Aboriginal participants, appropriate corporate structures, appropriate scale of enterprise, accommodation of cultural and social factors, educating the industry and consumers, and realistic subvention. ${ }^{46}$ They also conclude their analysis as follows: ${ }^{47}$

"The cultural sustainability of Aboriginal participation will be largely dependent on Aboriginal control of the extent and nature of such participation. It is imperative that any government initiatives for Aboriginal participation recognize the fragility of the Aboriginal cultural product so that undue pressure is not placed on Aboriginal suppliers of cultural tourism to meet the needs of the tourism market. The sustainability of Aboriginal cultural tourism will be largely dependent on an appropriately slow rate of development that can best be described as tourism realism"

As discussed above much of the Australian legislative framework for indigenous peoples is derived from international legal instruments. These principles are reflected in Australian legislation through Acts such as the Aboriginal Land Rights (Northern Territory) Act 1979 and Native Title Act 1993 (Cth). Additionally, cases such

44 Regulation of Bali Province No. 2 Year 2012 concerning Culture Tourism of Bali, Article 3 juncto Regulation of Bali Province No. 10 Year 2015 concerning Master Plan of the Bali Province Tourism Development Year 2015 - 2029, Article 9.

45 See for example Katharine Booth and Lisa Ford, Ross $v$ Chambers, 2016, Assimilation law and policy in the Northern Territory, in Aboriginal History Vol. 40, (ANU Press and Aboriginal History Inc, 2016), 6.

46 Jon Altman and Julie Finlayson, "Aborigines, Tourism and Sustainable Development," The Journal of Tourism Studies 14, No. 1, (2003): 83 https://www.jcu.edu.au/_data/assets/pdf_file/0011/122204/ jcudev_012859.pdf

47 Ibid., 89. 
as $M a b o^{48}$ and $W i k^{49}$ have provided the impetus for legislative responses to these changes in jurisprudence in relation to indigenous peoples in Australia. An interesting juridical analysis on Mabo case can be read in an article written by Kent McNeil that discusses the consequence of the impairment of Indigenous land rights through the creation of third-party interests by Crown grant. ${ }^{50}$ Mabo was a landmark case in which the High Court boldly held that the denial of Indigenous land rights by governments and judges after over two hundred years had been based upon the erroneous application of the common law. ${ }^{51}$

International instruments and Australian law promote the protection of economic and social and cultural protection or development of indigenous peoples. However, no explanation of what these terms mean is given and, more importantly, no explanation of what these terms mean to the indigenous peoples is given. As the Balinese are demonstrating, and equally relevantly to Australia, an understanding of these terms is critical to determining fair and just outcomes for the peoples involved.

Australian approach has been, and still is, the trichotomy of economic and social and cultural factors, each with its own measure, whether those measures are financial or the intangible value of the human condition. This trichotomous approach translates easily to the hegemony in Australia but perhaps loses efficacy when applied to the indigenous peoples; particularly with their spiritual connection to the land and community, which is more aligned with the Balinese approach.

While Australia is one step ahead in managing the Indigenous culture than Indonesia, there is no clear explanation whether the Aboriginal culture in Australia is, or could be, recognized and protected as an economic resource. The tourism industry is about 3\% of the Australia national economy and it also helps to create opportunities for employment (8\% of Australia's employment arises from tourism industry; over 900,000 people). ${ }^{52}$ For instance, the New South Wales Government, through the Office of Environment and Heritage $(\mathrm{OEH})$, gives the New South Wales National Parks and Wildlife Service (NPWS) the authority to conserve and protect the natural environment, Aboriginal Country, culture and heritage and the built heritage of New South Wales.They are committed to promoting original tourism whilestill respecting the unique Aboriginal tradition and developing a network of partnerships to support the tourism industry. ${ }^{53}$ The New South Wales Government is also in the process of creating a policy that will arrange the standards of how to treat Aboriginal cultural heritage without decreasing its originality. Before making a proper cultural

48 Mabo v Queensland [No 2] (1992) 175 CLR 1.

49 The Wik Peoples v Queensland (1996) 141 ALR 129.

50 Kent McNeil, "The Vulnerability of Indigenous Land Rights in Australia and Canada," Osgoode Hall Law Journal 42.2 (2004): 271-301. http://digitalcommons.osgoode.yorku.ca/ohlj/vol42/iss2/3.

51 Ibid., 273.

52 Cultural Tourism Development Program: An Introduction to the Tourism Industry and Business Development, 15.

53 Op.cit., 4. 
tourism policy, the New South Wales Government is observing and learning tourism the cultural system itself. There are four mutually related elements in the tourism system that could not run separately, namely consumers ${ }^{54}$, travel experience ${ }^{55}$, holiday experience ${ }^{56}$ and marketing promotion. ${ }^{57}$

\subsection{The Sufficiency of Indonesian Law to Protect the Indigenous Culture as an Economic Resource (the Case of Bali)}

In relation to the Indonesian regulations above, indigenous people and cultural regulations are the primary pillars of tourism. The indigenous people, their rights, and Desa Adat are recognized and protected under the Indonesian Constitution 1945. The regulations of indigenous peoples are spreading into different legislation, such as the Indonesian Human Rights Act, the Indonesian Tourism Act, ${ }^{58}$ the Indonesian Forestry Act No. 18 Year 2013, and the Indonesian Village Act No. 6 Year 2014.

As previously discussed, there are some Indonesian regulations that cover the issue of indigenous culture. The Indonesian Tourism Act determines that one of the Indonesian tourism objectives is to enhance the culture. ${ }^{59}$ The Government and the Private Sector also have an obligation to maintain and develop the indigenous culture as a tourist attraction. However, those obligations are not clear enough in terms of what kind of maintenance and what kind of development they must do in conserving the indigenous culture itself. ${ }^{60}$ On the other side, the indigenous people could take a part maintaining, conserving and developing the culture, but the benefits only go to the Government and the private sector. Unfortunately, the four pillars of Cultural Development in Bali apply to the Government and the private sector rather than to the indigenous people as the owner of the indigenous culture. Unfortunately, both the Government and private sector do not seem to realize that indigenous culture significantly effects tourism.In this regard, local governments should identify which private sectors may become their partners in dealing with the Balinese indigenous culture, for instance in implementing Corporate Social Responsibility (CSR) schemes. ${ }^{61}$

\footnotetext{
54 Consumers are persons who might be in holidays, See Ibid., 17.

55 Travel experience is experience of the consumers when they are travelling to their destinations, Ibid.

56 Holiday experience is the consumers experience when they are enjoying their holiday in the destinations, Ibid.

57 The good marketing promotion of tourism is based on research, development, situation and two ways communication with the consumers. It will increase the awareness of consumer needs and sales at once, Ibid.

58 Indonesian Tourism Act, Article 5 (e): "Tourisms shall be implemented based on the principles below: make efficient use of the local community. It means the local community or indigenous people have the rights to participate in maintain and develop the tourism".

59 Ibid., Article 4 (f).

60 Ibid., Article 23 and 26: "......the Government and the Private Sectors are obliged to conserve the culture in properly as a national assets to attract tourists....."

61 According to Article 74 paragraph 1 of the Limited Company Act No. 40 Year 2007, CSR is mandatory for the Limited Company in Indonesia.
} 
A CSR calculation is based on the company income each year (percentage), and the output from the CSR will be used for maintaining, managing or conserving the indigenous culture.

A lesson-learned may be seen in the cultural commodification of some elements of culture, such as the system of belief and art, that occurred in Bali. ${ }^{62}$ Some villages in Bali combined a unique religious-traditional ceremony of $\mathrm{Ngaben}^{63}$ with a tourist event. One of the best examples may be seen in Ubud village where the Ubud Village Government jointly cooperates with the Puri Ubud to perform a royal cremation in performing this cultural event. A lot of domestic and foreign tourists come to see the ceremony as well as local and foreign television stations. ${ }^{64}$ It shows that $N g a b e n$, as one of the indigenous cultures, has successfully attracted tourists to come to Ubud Village and help the tourism industry grow.

The way of life of the Balinese indigenous peoples is their tradition. Tourists come to Bali for the Balinese tradition. They are curious and love to watch the Balinese ceremonies. Thus, the Balinese indigenous peoples must maintain and develop the Balinese culture in order to keep it sustained. In other words, the Balinese culture has an economic value for the Balinese peoples.

Hindu families are not forced to spend their money to conduct the daily ceremonial activities, but that is a form of their religious practice as they incorporate their religion into their daily life. Moreover, the Balinese peoples (especially Hindu peoples) have the Tri Hita Karana philosophy, the three relationships between the individual and their God, between the individual and other individuals, and between the individual and the environment. They believe in that philosophy and must implement it in their daily life to keep Bali in harmony.

It may be argued that Indonesian laws and regulations are not sufficient to protect the indigenous culture as they do not regard the culture as a tourism economic resource. Conversely, in fact, the Balinese tradition is a tourism economic resource.

Refers to that situation, there are difficulties defining culture. The Indonesian Tourism Act does not define exactly what culture is. The definition of the subject of policy is one of the most fundamental elements of policy construction and analysis. ${ }^{65}$

62 See I Made Sendra, "Komodifikasi Informasi Pariwisata Budaya Fungsi dan Makna Upacara Memasuki Usia Dewasa Di Jepang Dan Bali: Perspektif Lintas Budaya," Analisis Pariwisata 13, No. 1 (2013): 46. https://fpar.unud.ac.id/ind/wp-content/uploads/2014/03/Jurnal-Pariwisata-Vol.13-No.1-2013.pdf Researchers in social and humanities disciplines use commodification theory to view the development of Ngaben ceremony in Bali. See for instance sociological theory of religion commodification in Nengah Bawa Atmadja dan Tuty Maryati, Geria Pusat Industri Banten Ngaben di Bali Perspektif Sosiologi Komodifikasi Agama, Kawistara 4, No. 2, (2014): 164. https://jurnal.ugm.ac.id/kawistara/article/view/5670/4624

63 Ngaben is a Balinese-Hindu ceremony for the death body. Generally, there aresome processess of Ngaben, started from Nyiramin (bath the death body), put the death body in a peculiar tool (it called wadah), take the death body to the cemetery, do the cremation, and take the ash of the cremation to the sea.

64 See http://www.greenerbali.com/ngaben.html.

65 Akira Iida. Paradigm Theory \& Policy Making: Reconfiguring The Future, $1^{\text {st }}$ edition, (Japan: Tutle Publishing, 2004), 17. 
The definition is considered as the very basic requirement for construction of the logical concept. The problem of definition is the fundamental problem of scientific work, particularly of those related to the development of concepts. ${ }^{66}$ That is why the definition of the culture shall be clear enough. In other words, there is an abstention of the norm that regulating culture as a tourism economic resource.

It can be expected that the Indonesian Government will review the Indonesian Tourism Act as well as Government of Bali Province that will amend Regulations No. 2 Year 2012 and No. 10 Year 2015, or even enact new legislation or local regulations that would define and regulate indigenous culture as an economic resource. ${ }^{67}$ Such legislation or regulation should also contain the identification of the indigenous culture; the rights and obligations of the Government, the private sector and the indigenous people towards the indigenous culture. Those conditions could give justice, expediency and legal certainty to the indigenous peoples (including the Balinese peoples) as the owner of their culture. It is contrary to the rechtsidee of the purposes of law as mentioned above by Gustav Radbruch. ${ }^{68}$

A good policy or regulation is made from the needs and the expectations of the communities the policy effects. As Myres S. Mc Dougal stated in his policy-oriented theory, making a policy or decision must be start from the community process context, which community will respond to and receive the decision, what is the value of the decision and what are the community expectations. ${ }^{69}$ The appropriate method to know the community's needs and expectations is a bottom-up approach. It must come up from the bottom (the community), not from the top (the Government). According to the Article 5 (e) of the Indonesian Tourism Act, the bottom-up approach is explicitly recognized but the problem is the community (including the indigenous peoples) does not seem to be aware of it. Even though the community is not aware of their participation in tourism, the Indonesian Government should be active to see and observe the phenomena of tourism related to the existence of culture as an economic resource.

\section{Conclusion}

The Indigenous Peoples of Indonesia (the Province of Bali) and Australia are facing similar issues in relation to the pressures that non-traditional factors are

66 I.B. Wyasa Putra, "Indonesian Tourism Law: In Search of Law and Regulations Model," 1 Lex Mercantoria Journal of International Trade and Business Law, (2013): 63.

67 See Introduction part, 7, the Indonesia Constitutional Court Decision, loc.cit. A specific regulation is needed for the natural resource (in this case forest) which is owned by the indigenous people. The regulation will protect, utilize and manage the forest properly in order to give benefit and prosperity to the indigenous people as the owner and citizens around it.

68 Theo Hujbers, Filsafat Hukum Dalam Lintasan Sejarah (Yogyakarta: Kanisius, 1993), 161-166.

69 See Myres S. McDougal, Law as a Process of Decision: A Policy-Oriented Approach to Legal Study (USA: Yale Law School Scholarship Resipotory, 1956), 56 and I.B. Wyasa Putra, Teori Hukum Dengan Orientasi Kebijakan (Policy-Oriented Theory of Law): Pemecahan Problem Konteks Dalam Proses Legislasi Indonesia, (Denpasar: Udayana University Press, 2016), 107. 
placing on their traditional way of life and social systems. The international instruments to protect the indigenous people rights are the same for both nations, and both have implemented the principles with varying degrees of success.

The people of Bali have identified the notion of "culture as an economic tourism resource" and are seeking to amend the law to reflect the innate economic value of a culture. This principle aligns with the principle of Tri Hita Karana and, as a people, they do not distinguish between economic and cultural value. Unfortunately, the Indonesian laws and regulations that relate to the indigenous people and their culture are not sufficient to protect the indigenous culture as an economic tourism resource.

The Indonesian Tourism Act does not contain the definition of culture, which has created a problem of definition. In contrast, the Australian approach has been, and still is, a trichotomy of economic, social and cultural factors, each with its own measure, either financial or the intangible value of the human condition.

The issue of protecting indigenous cultures is vexed and laden with misunderstandings. However, this only makes finding a workable and sustainable solution even more important. Moving forward, the Balinese people may derive some benefit from analyzing their cultural traditions and values using a paradigm that economic, social and cultural activities are, or can be, uniquely identified and, consequently, protected using the existing framework of regulation. Thus, the Indonesian Government must review the Indonesian Tourism Act or enact a specific act for the Indigenous peoples and their culture which creates a clear and appropriate definition of culture, which is includes culture as an economic resource.Especially in Bali, the local government should draft a new local regulation to protect the indigenous culture itself.This regulation should contain the kinds of the Balinese indigenous culture, and the rights and obligations of the Government, the private sector, and the indigenous Balinese people.

The opposite may hold true for the Australian context where the Aboriginal culture is not the primary driver of its tourism. Australia is recognized as an ecotourism destination, but the New South Wales Government is creating a cultural tourism development program to increase the tourism industry (including the Aboriginal culture). Thus, even though the Aboriginal culture is not the primary source of Australian tourism and there is no law which defines Aboriginal culture as one of Australia's economic resources, the New South Wales Government in the process of making an appropriate policy to maintain the Aboriginal Culture.

This is a complex area of jurisprudence, due to the complexity of the subject matter, and the inherent, and often-unknown, effect that the commentator's own 
culture brings to any observation. It is also from this complexity that new solutions may grow as understanding of alternative paradigms develops.

\section{BIBLIOGRAPHY}

\section{Book}

Booth, Katharine, and Lisa Ford. "Ross v Chambers: Assimilation law and policy in the Northern Territory." Aboriginal History 40 (2016): 3-25.

Hujbers, Theo. Filsafat Hukum Dalam Lintasan Sejarah. Yogyakarta: Kanisius, 1993.

Hutchinson, Terry. Researching and Writing in Law. Sydney: Lawbook Co., 2002.

Iida, Akira. Paradigm Theory \& Policy Making: Reconfiguring The Future, $1^{\text {st }}$ Edition. Japan: Tuttle Publishing, 2004.

McDougal, Myres S. Law as a Process of Decision: A Policy-Oriented Approach to Legal Study. USA: Yale Law School Scholarship Resipotory, 1956.

Pasek Diantha, I Made. Metodologi Penelitian Hukum Normatif dalam Justifikasi Teori Hukum. Jakarta: Prenada Media Group, 2016.

Sirtha, I Nyoman. Aspek Hukum Dalam Konflik Adat Bali. Denpasar: Udayana University Press, 2008

Soekanto, Soerjono and Sri Mamudji. Penelitian Hukum Normatif: Suatu Tinjauan Singkat. Jakarta: Raja Grafindo Persada, 2001.

Putra, I.B. Wyasa. Teori Hukum Dengan Orientasi Kebijakan (Policy-Oriented Theory of Law): Pemecahan Problem Konteks Dalam Proses Legislasi Indonesia. Denpasar: Udayana University Press, 2016.

\section{Journal}

Altman, Jon and Julie Finlayson. "Aborigines, Tourism and Sustainable Development." The Journal Of Tourism Studies 14, No. 1, (2003): 78-91 https://www.jcu.edu. au/_data/assets/pdf_file/0011/122204/jcudev_012859.pdf

Atmadja, Nengah Bawa and Tuty Maryati. "Geria Pusat Industri Banten Ngaben di Bali Perspektif Sosiologi Komodifikasi Agama.” Jurnal Kawistara 4, no. 2 (2014): 162-176. https://doi.org/10.22146/kawistara.5670

Barratt, Amanda, and Ashimizo Afadameh-Adeyemi. "Indigenous peoples and the right to culture: The potential significance for African indigenous communities of the Committee on Economic, Social and Cultural Rights' General Comment 
21." African Human Rights Law Journal 11, no. 2 (2011): 560-587. http://hdl. handle.net/10520/EJC51950

Gunn, Brenda L. "Protecting Indigenous Peoples' Lands: Making Room for the Application of Indigenous Peoples' Laws Within the Canadian Legal System." Indigenous Law Journal 6, Issue 1 (2007): 31-69.

McNeil, Kent. "The vulnerability of Indigenous land rights in Australia and Canada." Osgoode Hall Law Journal 42. No. 2 (2004): 271-301. http://digitalcommons. osgoode.yorku.ca/ohlj/vol42/iss2/3

Salain, Made Suksma Prijandhini Devi. "Perlindungan Hukum Terhadap Kebudayaan Bali Sebagai Sumber Daya Ekonomi Pariwisata." Kertha Patrika 39, No. 01 (2017): 1-15. https://doi.org/10.24843/KP.2017.v39.i01.p01

Sendra, I Made. "Komodifikasi Informasi Pariwisata Budaya Fungsi Dan Makna Upacara Memasuki Usia Dewasa Di Jepang Dan Bali: Perspektif Lintas Budaya.” Analisis Pariwisata 13, No. 1 (2013).

Sonata, Depri Liber. "Metode Penelitian Hukum Normatif dan Empiris: Karakteristik Khas dari Metode Meneliti Hukum." Jurnal Fiat Justisia 8, no. 1 (2014). https:// doi.org/10.25041/fiatjustisia.v8no1.283

Subadra, I Nengah, I Wayan Arta Artana, I Made Bayu Wisnawa. "Pura di Tanah Lot: Konflik di Obyek dan Daya Tarik Wisata Global." Jurnal Perhotelan dan Pariwisata 6, No.1 (2016): 51-72.

Triari, Putri, Kali Jones, and Ni Gusti Ayu Dyah Satyawati. "Indigenous People, Economic Development and Sustainable Tourism: A Comparative Analysis between Bali, Indonesia and Australia." Udayana Journal of Law and Culture 1, no. 1 (2017): 16-30. https://doi.org/10.24843/UJLC.2017.v01.i01.p02

Putra, I.B. Wyasa. "Indonesian Tourism Law: In Search of Law and Regulations Model." 1 Lex Mercatoria: Journal of International Trade and Business Law, (2013): 57.

\section{Legal Document}

Universal Declaration of Human Rights (UDHR) 1948.

International Labour Organisation (ILO) Convention on Indigenous and Tribal 
Populations 1957 (No. 107).

International Covenant on Economic, Social and Cultural Rights (ICESCR) 1966.

International Labour Organisation (ILO) Convention on Indigenous and Tribal Peoples 1989 (No. 169).

General Agreement on Trade in Services (GATS) 1994.

Global Code of Ethics for Tourism (GCET) 1999.

United Nations Declaration on the Rights of Indigenous Peoples (UNDRIP) 2007

General Assembly of the United Nations, A/65/275, Sixty-Fifth Session, Item 20 of the provisional Agenda, "Sustainable Development, Implementation of the Global Code of Ethics for Tourism", 10 August 2010, http:/ cf.cdn.unwto.org/ sites/all/files/pdf/item_7a.pdf

Indonesia Constitutions 1945.

Indonesia Constitutional Court Act No. 24 Year 2003.

Indonesia Limited Company Act No. 40 Year 2007.

Indonesia Tourism Act No. 9 Year 2010.

Indonesia Formatting Regulations Act No. 12 Year 2011.

Indonesia Village Act No. 6 Year 2014.

Indonesia Local Government Act No. 23 Year 2014.

Government Regulation No. 50 Year 2011 concerning Master Plan of National Tourism Development Year 2010 - 2025.

Constitutional Court Regulations No. 06/PMK/2005 concerning the Guideline of the Judicial Review Procedures.

Regulation of Bali Province No. 3 Year 2001 concerning Desa Pakraman.

Regulation of Bali Province No. 2 Year 2012 concerning Culture Tourism of Bali.

Regulation of Bali Province No. 10 Year 2015 concerning Master Plan of the Bali Province Tourism Development Year 2015 - 2029.

Aboriginal Land Rights (Northern Territory) Australia Act 1979. 
Native Title Australia Act 1993 (Cth).

\section{Other Document}

Ashley, Caroline, Peter de Drine, Amy Lehr, and Hannah Wilde. "The Role of the Tourism Sector in Expanding Economic Opportunity." Corporate Social Responsibility Initative Report, No. 23, Cambridge, MA: Kennedy School of Government, Harvard University, 2007

Colquhoun, Simon and Alfred Michael Dockery. "The link between Indigenous culture and wellbeing: Qualitative evidence for Australian Aboriginal peoples." CLMR Discussion Paper Series 2012/01. http://ceebi.curtin.edu.au/local/ docs/2012.01_LSIC_qualitative_CLMR1.pdf

Sudantra, I Ketut. "Pelaksanaan Fungsi Hakim Perdamaian Desa dalam Kondisi Dualisme Pemerintahan Desa di Bali." Thesis S2 Ilmu Hukum Program Pasca Sarjana Universitas Udayana, 2007.

Wyasa Putra, I.B. "A Contra-productive Impact of Indonesian New Legislation on Administrative Village against Indonesian Indigenous Culture as an Economic Resources." International Conference on Access to Justice for Indigenous Peoples. Malaysia: Faculty of Law University of Malaya, 2015

\section{Case Law}

Indonesia Constitutional Court Decision No. 35/PUU-X/2012

Mabo v Queensland [No 2] (1992) 175 CLR 1

The Wik Peoples $v$ Queensland (1996) 141 ALR 129

\section{Website Content/Internet}

DeMarco, Claire. “Legal Research Strategy,” http:/ / guides.library.harvard.edu/law/ researchstrategy/primarysources

http: / bali.tribunnews.com/2017/07/26/ini-alasan-pura-ulun-danu-beratan-ditutup-puluhan-orang-berpakaian-adat

http://study.com/academy/lesson/what-are-economic-resources-defini-tiontypes-examples.html

http:/ / www.balipost.com/news / 2017/04/30/7149/Wajib-Libatkan-Desa-AdatDalam.html

http: / / www.jawapos.com/radarbali / read/2017 / 07 / 26/3807 / gawat-obᄀjek- 
wisata-danau-beratan-disegel-warga

https: / / www.ag.ndsu.edu/agriculturalmanagement/agmgmt/coursemate-rials / econresources

smallbusiness.chron.com/economic-definition-four-factors-production-3941.html

Lowe, Kirstie and Stephen Ollerenshaw. "Cultural Tourism Development Program An Introduction to the Tourism Industry and Business Development." http:// www.environment.nsw.gov.au/resources/parksecopass/CTDProgram.pdf

New South Wales Destination. "Cultural and Heritage Tourism to NSW Year Ended December 2016." https:/ / www.destinationnsw.com.au/wp-content/uploads / 2013/05/Cultural-and-Heritage-Tourism-to-NSW-Snapshot-YE-Dec-2016.pdf

Top 10 Tourist Attractions in Australia, www.touropia.com/tourist-attractions-inaustralia/ 